\title{
IDENTIFIKASI PERMASALAHAN PENGANGGURAN: STUDI KASUS DI PEDESAAN (DESA SELAT, KABUPATEN KLUNGKUNG)
}

\author{
Ni Nyoman Reni Suasih ${ }^{1}$ Ni Luh Karmini ${ }^{2}$
}

Article history:

Submitted:

30 Oktober 2021

Revised:

20 November 2021

Accepted:

24 November 2021

\section{Keywords:}

Unemployment;

RuralPedesaan;

Labor market.

\section{Kata Kunci:}

Pengangguran;

Pedesaan;

Pasar tenaga kerja.

\section{Koresponding:}

Fakultas Ekonomi dan Bisnis Universitas Udayana, Bali, Indonesia

Email: renisuasih@unud.ac.id

\section{Abstract}

Unemployment is one of the macroeconomic problems that hinder regional development because it will cause other social problems. The phenomenon of unemployment in rural areas is a serious problem for Selat Village, Klungkung Regency. This study aims to identify conditions and factors causing unemployment, as well as labor market conditions in Selat Village. The data in this study were collected through questionnaires, interviews, and FGD techniques. Furthermore, the data were analyzed through quantitative and qualitative descriptive analysis techniques. The results of the analysis show a picture of employment in Selat Village, where the percentage of the population of working age who does not work is quite high, namely $33.85 \%$. Although the demand for labor in Selat Village is not nearly as high as in urban areas, people who do not work are reluctant to migrate to cities. The labor market is segmented into the formal sector and the informal sector. The causes of unemployment can be classified into factors of education, skills, wages, information, and the availability of jobs. Further research is needed on Alternative Livelihoods.

\begin{tabular}{l} 
Abstrak \\
\hline Pengangguran merupakan salah satu masalah makro ekonomi yang \\
menghambat pembangunan daerah karena akan menimbulkan masalah- \\
masalah sosial lainnya. Fenomena pengangguran di pedesaan menjadi \\
masalah serius bagi Desa Selat, Kabupaten Klungkung. Penelitian ini \\
bertujuan untuk mengidentifikasi kondisi dan faktor penyebab \\
pengangguran, serta kondisi pasar tenaga kerja di Desa Selat. Data pada \\
penelitian ini dikumpulkan melalui teknik kuesioner, wawancara, dan FGD. \\
Selanjutnya data dianalisis melalui teknik analisis deskriptif kuantitatif dan \\
kualitatif. Hasil analisis menunjukkan gambaran ketenagakerjaan di Desa \\
Selat, dimana persentase penduduk pada usia kerja yang tidak bekerja \\
tercatat cukup tinggi, yaitu 33,85\%. Meskipun permintaan tenaga kerja di \\
Desa Selat hampir tidak setinggi di perkotaan, namun masyarakat yang tidak \\
bekerja enggan untuk bermigrasi ke kota. Pasar tenaga kerja tersegmentasi \\
menjadi sektor formal dan sektor informal. Penyebab menganggur dapat \\
diklasifikasikan atas faktor pendidikan, keterampilan, upah, informasi, dan \\
ketersediaan lapangan pekerjaan. Perlu dilakukan penelitian lanjutan \\
mengenai Mata Pencaharian Alternatif (MPA).
\end{tabular}

Fakultas Ekonomi dan Bisnis Universitas Udayana, Bali, Indonesia ${ }^{2}$

Email:karmini@unud.ac.id 


\section{PENDAHULUAN}

Pembangunan dapat diartikan sebagai suatu upaya serta proses perubahan atau transformasi ekonomi, sosial dan budaya secara sengaja dan terencana melalui berbagai kebijakan untuk menjadi lebih baik (Kartasasmita, 1996; Riyadi \& Bratakusumah, 2005; Siagian, 1994; Tikson, 2005). Sedangkan pembangunan desa juga dapat dipandang sebagai suatu program pembangunan yang dilakukan secara berencana untuk meningkatkan produksi, pendapatan, dan kesejahteraan dalam arti peningkatan kualitas hidup dibidang pendidikan, kesehatan dan perumahan (Kartasasmita, 1996). Terdapat dua aspek penting dalam pembangunan desa, yaitu aspek fisik dan aspek pemberdayaan insan (Adisasmita, 2006).

Masalah pengangguran merupakan salah satu masalah makro ekonomi yang menghambat pembangunan daerah karena akan menimbulkan masalah-masalah sosial lainnya. Pengangguran merupakan suatu kondisi dimana seseorang yang tergolong dalam angkatan kerja ingin mendapatkan pekerjaan tetapi belum dapat memperolehnya (Sukirno, 2006; Yanuar, 2009). Mengurangi pengangguran dan mencapai tingkat pertumbuhan ekonomi yang tinggi merupakan prioritas utama negara maju maupun negara berkembang, termasuk Indonesia (Djafar \& Kurniasih, 2015). Pengangguran di Indonesia didominasi oleh kelompok muda yang relatif memiliki pendidikan tinggi dan tinggal bersama orang tua (Suryadarma et al., 2005).

Semakin terbatasnya lapangan pekerjaan, khususnya di wilayah perdesaan, maka akan semakin tinggi tingkat pengangguran (sebagaimana digambarkan pada Gambar 1) dan urbanisasi di kalangan masyarakat desa (Wijaya et al., 2020). Permasalahan tersebut bukan hanya menjadi sebuah permasalahan biasa, karena bila dibiarkan akan berdampak pada tidak produktifnya desa akibat dari tidak adanya aktivitas-aktivitas yang dapat menghasilkan nilai ekonomis di wilayah perdesaan (Wijaya et al., 2020).

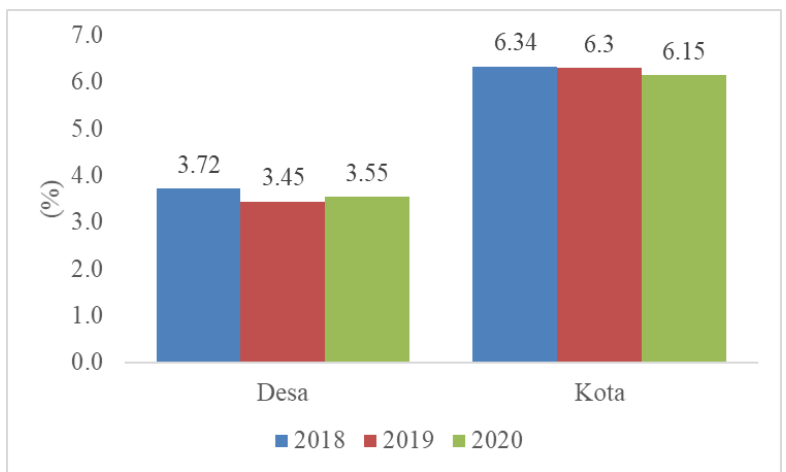

Sumber: Badan Pusat Statistik, 2020 (diolah)

Gambar 1.

Perbandingan Tingkat Pengangguran Terbuka (\%) Desa dan Kota di Indonesia

Desa Selat yang terletak di Kabupaten Klungkung merupakan desa yang memiliki jumlah pengangguran cukup tinggi (Desa Selat, 2019). Berdasarkan data yang diperoleh dari hasil observasi awal diketahui bahwa bidang mata pencaharian utama masyarakat di Desa Selat adalah pertanian, namun persentasenya masih lebih kecil dibandingkan persentase pengangguran. Tingginya jumlah pengangguran di Desa Selat, Kabupaten Klungkung menjadi suatu hal yang sangat menarik untuk diteliti. Penelitian tentang identifikasi dan analisis pengangguran ini merupakan awal untuk melakukan penelitian 
lanjutan seperti analisis potensi dan mata pencaharian alternatif (MPA) bagi masyarakat lokal, dengan harapan akan memberikan suatu referensi kebijakan untuk menangani masalah tersebut. Adapun tujuan yang ingin dicapai dari pelaksanaan penelitian ini yaitu untuk mengidentifikasi kondisi pengangguran, kondisi pasar tenaga kerja, dan faktor-faktor yang menyebabkan tingginya tingkat pengangguran di Desa Selat, Kabupaten Klungkung.

\section{METODE PENELITIAN}

Penelitian ini menggunakan metode pendekatan empiris, dimana metode ini menjelaskan penelitian secara umum-khusus dan semua ilmu pada metode ini berasal dari pemakaian intelektual yang dibangun di atas kemampuan argumentasi secara logika, juga menyatakan bahwa ilmu yang valid adalah merupakan abstraksi, simplikasi atau idealisasi dari realitas dan terbukti koheren dengan sistem logikanya.

Pengumpulan data pada penelitian ini dilakukan melalui 3 (tiga) teknik, yaitu melalui kuesioner, wawancara, dan FGD. Total responden sebagai populasi dalam penelitian ini adalah seluruh pengangguran di Desa Selat yang berjumlah 1.400 orang. Sedangkan jumlah sampel ditentukan secara purposive yaitu sebanyak 140 orang yang akan ditentukan secara accidental. Teknik analisis data yang digunakan pada penelitian ini adalah teknik analisis deskriptif, dimana pendekatan utama kuantitatif namun tetap ditunjang oleh analisis kualitatif. Metode deskriptif analisis dengan pendekatan kuantitatif, yaitu hasil penelitian yang kemudian diolah dan dianalisis untuk diambil kesimpulannya, artinya penelitian yang dilakukan adalah penelitian yang menekankan analisisnya pada data-data numerik (angka) dengan menggunakan metode penelitian ini akan diketahui pengaruh yang signifikan antara variabel yang diteliti, sehingga menghasilkan kesimpulan yang akan memperjelas gambaran mengenai objek yang diteliti (Marini \& Putri, 2020).

\section{HASIL DAN PEMBAHASAN}

Profil Ketenagakerjaan di Desa Selat. Penduduk merupakan salah satu modal dasar yang utama dalam pelaksanaan pembangunan dalam suatu negara, apabila optimalisasi dalam pemanfaatanya dapat diterapkan dengan dukungan kualitas dari jumlah penduduk yang ada. Akan tetapi ketika kualitas penduduk maupun daya tampung lingkungan yang ada tidak memadai atau tidak seimbang dengan kualitas penduduk, maka akan terjadi permasalahan sektor yang kompleks yang berdampak pada ketentraman Negara.

Pengangguran masih menjadi masalah kependudukan di berbagai negara berkembang seperti Indonesia. Persoalan pengangguran bukan hanya menyangkut masalah ekonomi, melainkan juga masalah sosial (Sugianto \& Permadhy, 2020). Pengangguran berdampak sangat kompleks bagi pembangunan, baik jangka panjang maupun jangka pendek (Arsyad, 2010).

Gambar 2 berikut menunjukkan gambaran ketenagakerjaan di Desa Selat, dimana persentase penduduk pada usia kerja 
yang tidak bekerja tercatat cukup tinggi, yaitu 33,85 persen.

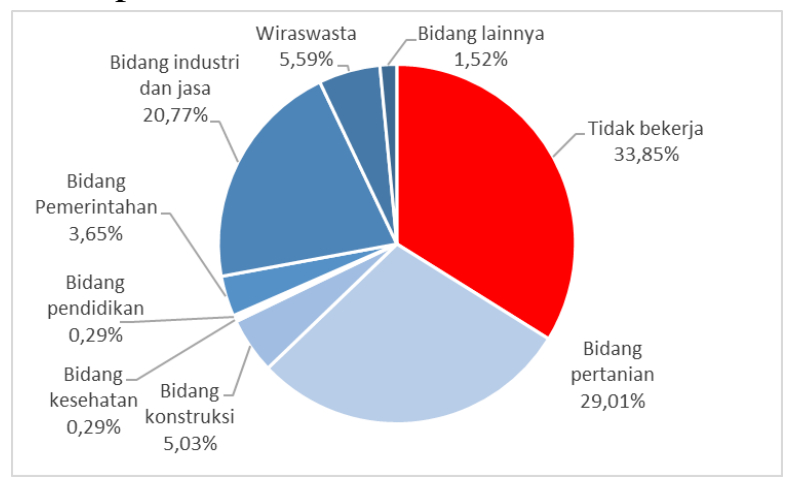

Sumber: Profil Desa Selat, 2019 (diolah)

Gambar 2.

Gambaran Ketenagakerjaan di Desa Selat

Gambar 2 juga menunjukkan bahwa dominan penduduk di Desa Selat memilih profesi di bidang pertanian (dalam arti luas), baik sebagai petani, peternak, maupun nelayan. Selain itu, jenis pekerjaan lainnya tersebar dalam berbagai bidang, seperti industri dan jasa (formal maupun informal), wiraswasta, pemerintahan, konstruksi (buruh bangunan), dan lainnya. Pilihan pekerjaan ini terkait dengan ketersediaan lapangan pekerjaan di Desa Selat.

Kondisi Pasar Tenaga Kerja di Desa Selat. Struktur perekonomian Desa Selat dominan bercorak agraris dan menitikberatkan pada sektor pertanian. Hal ini didukung oleh penggunaan lahan sawah masih menempati porsi terbesar (kurang lebih 34,6 persen) dari total pemanfaatan lahan di wilayah Desa Selat. Selain itu diketahui bahwa mata pencaharian dominan masyarakat Desa Selat adalah dalam bidang pertanian (kurang lebih 29,01 persen). Adapun sektor komoditas pertanian yang paling menonjol adalah padi.
Beberapa sektor ekonomi yang tergolong mendasar dan menonjol disamping sektor pertanian adalah pertenakan, perkebunan, perdagangan dan industri rumah tangga. Pada sektor pertanian di Desa Selat yang menononjol adalah padi, palawija, hortikultura. Sedangkan di sektor peternakan yang banyak dipelihara warga adalah ternak sapi, ayam (ras dan buras), babi dan itik. Hasil tegalan/kebun adalah kelapa, pisang, cengkeh, nangka, rambutan, durian dan lainlain. Disamping itu pada lahan perkebunan masyarakat banyak menanam kayu sebagai usaha sampingan seperti albesia, sengon dan kayu jati.

Pada sektor perdagangan, Desa Selat memiliki 1 (satu) fasilitas pasar yang cukup memadai yang banyak didatangi oleh masyarakat dari Desa Akah, Selat, Selisihan serta sekitar Desa Tangkup (Karangasem), sebelah utara Desa Selat seperti Desa Pesaban, Nongan bahkan Rendang dan Menanga.

Pasar tenaga kerja, seperti pasar lainnya dalam perekonomian dikendalikan oleh kekuatan penawaran dan permintaan, namun pasar tenaga kerja berbeda dari sebagian besar pasar lainnya karena permintaan tenaga kerja merupakan tenaga kerja turunan (derived demand) dimana permintaan akan tenaga kerja sangat tergantung dari permintaan akan output yang dihasilkannya (Borjas, 2010; Mankiw, 2013).

Sebagaimana dijelaskan dalam asumsi teori Arthur Lewis dalam Jhingan (2003), bahwa perekonomian suatu negara terbagi menjadi dua sektor: (1) sektor tradisional yaitu sektor pertanian subsisten yang surplus tenaga kerja, dan tingkat upah yang rendah, 
dan (2) sektor industri perkotaan modern yang tingkat produktivitasnya tinggi dengan upah yang lebih tinggi pula, dan menjadi penampung transfer tenaga kerja dari sektor tradisional. Perbedaan tingkat upah tenaga kerja pada kedua sektor ini akan menarik banyak tenaga kerja untuk berpindah (migrasi) dari sektor pertanian ke sektor industri (Sulistiawati, 2012). Hal ini juga terjadi di Desa Selat, dimana meskipun masih terbuka peluang kerja di sektor pertanian, namun masyarakat lebih memilih untuk tidak bekerja dibandingkan bekerja di sektor pertanian dengan tingkat upah atau pendapatan yang relatif kecil.

Pada sektor industri rumah tangga dan pengolahan termasuk didalamnya adalah kerajinan emas dan perak, pembuatan kosen, jahit, anyaman bambu serta pengolahan hasil pertanian dan perkebunan. Perkembangan sektor jasa terlihat dari tumbuhnya lembaga/institusi Keuangan Mikro berupa Koperasi, LPD, Program Community Based Development (CBD) sebagai pendukung ekonomi desa. Hal ini diharapkan akan membawa dampak positif dalam perkembangan ekonomi desa secara keseluruhan. Kelebihan penawaran tenaga kerja di Desa Selat disinyalit akan diserap oleh sektor informal yang tingkat upah atau penghasilannya diharapkan lebih dari sektor pertanian. Temuan pada studi ini sejalan dengan model dual economy (Izzaty \& Sari, 2013) yang mengasumsikan perekonomian (pasar tenaga kerja) tersegmentasi menjadi sektor formal dan sektor informal, penetapan upah minimum akan mengurangi permintaan tenaga kerja di sektor formal, dan kelebihan penawaran tenaga kerja akan diserap sektor informal yang tingkat upahnya tidak diatur oleh regulasi.

Meskipun permintaan tenaga kerja di Desa Selat hampir sama seperti daerah pedesaan pada umumnya, yang tidak setinggi permintaan tenaga kerja di perkotaan, namun masyarakat yang tidak bekerja enggan untuk bermigrasi ke kota. Hal ini dijelaskan lebih lanjut sebagaimana hasil penelitian Knight et al., (2011) bahwa ada kecenderungan bahwa tenaga kerja di pedesaan enggan untuk bermigrasi ke kota disebabkan karena: (1) merasa terlalu tua; (2) perlu merawat tanggungan; (3) gagal memperoleh pekerjaan di kota. Selain itu kendala kelembagaan membuat kesulitan bagi migran yang tinggal di daerah perkotaan dalam hal pekerjaan yang baik dan aman, perumahan, dan akses ke layanan publik. Kondisi ini menghalangi atau mencegah para pekerja migran membawa keluarga mereka, yang pada gilirannya membuat banyak pekerja di desa enggan meninggalkan desa, setidaknya untuk waktu yang lama.

Faktor-faktor Penyebab Tingginya Tingkat Pengangguran di Desa Selat. Berdasarkan hasil tinjauan riset sebelumnya dan disesuaikan dengan hasil FGD, maka dapat diidentifikasi beberapa faktor penyebab terjadinya pengangguran. Dimana secara garis besar dapat diklasifikasikan atas faktor: (1) pendidikan, (2) keterampilan, (3) upah, (4) informasi, dan (5) ketersediaan lapangan pekerjaan.

Berdasarkan jawaban responden, terkait penyebab dan kondisi pengangguran di Desa Selat, maka berikut disajikan beberapa point hasil tabulasi data. Terkait faktor yang 
Identifikasi Permasalahan Pengangguran...

Ni Nyoman Reni Suasih \& Ni Luh Karmini

membuat menjadi pengangguran, Gambar 3 menyajikan alasan responden menganggur.

Faktor persaingan dianggap sebagai faktor yang paling berpengaruh sehingga membuat masyarakat menjadi pengangguran. Persaingan menunjukkan bahwa lapangan pekerjaan atau skill masyarakat cenderung homogen sehingga terjadi persaingan dalam memperoleh pekerjaan maupun ketika membuka usaha.

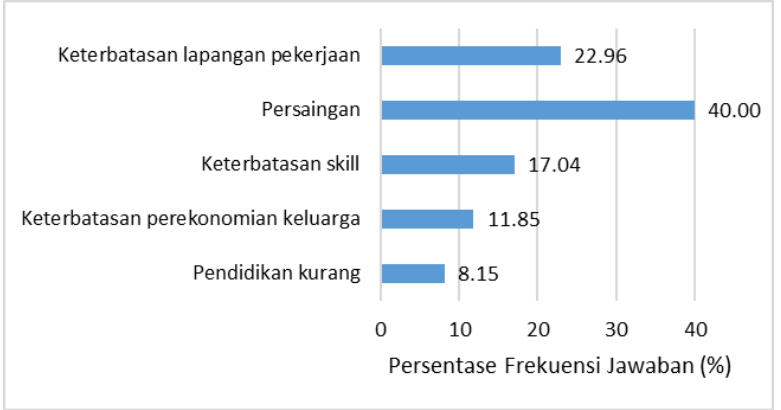

Gambar 3.

Grafik Persepsi Responden Mengenai Faktor yang Membuat Menjadi Pengangguran

Tabel 1.

Persentase Frekuensi Jawaban Responden Terkait Kondisi Pengangguran

\begin{tabular}{|c|c|c|c|c|c|}
\hline No & Uraian & \multicolumn{4}{|c|}{ Persentase Jawaban Responden (\%) } \\
\hline \multirow{2}{*}{1.} & \multirow{2}{*}{$\begin{array}{l}\text { Kesesuaian pendidikan } \\
\text { dengan pekerjaan } \\
\text { sebelumnya }\end{array}$} & Tidak sesuai & Kurang sesuai & Sesuai & Sangat Sesuai \\
\hline & & 27,41 & 33,33 & 25,93 & 13,33 \\
\hline \multirow[t]{2}{*}{2} & \multirow{2}{*}{$\begin{array}{l}\text { Cara mencukupi kebutuhan } \\
\text { hidup selama menjadi } \\
\text { pengangguran }\end{array}$} & $\begin{array}{l}\text { Sumbangan } \\
\text { keluarga }\end{array}$ & $\begin{array}{l}\text { Pinjaman } \\
\text { keluarga }\end{array}$ & Pinjaman teman & $\begin{array}{c}\text { Bantuan } \\
\text { Pemerintah }\end{array}$ \\
\hline & & 52,59 & 28,15 & 17,04 & 2,22 \\
\hline \multirow{2}{*}{3} & \multirow{2}{*}{$\begin{array}{l}\text { Frekuensi pelatihan } \\
\text { keterampilan yang pernah } \\
\text { diikuti dan diadakan di desa }\end{array}$} & Belum pernah & $1-2$ kali & 3-4 kali & $>4$ kali \\
\hline & & 38,52 & 50,37 & 9,63 & 1,48 \\
\hline \multirow{2}{*}{4} & \multirow{2}{*}{$\begin{array}{l}\text { Upah sebagai penentu dalam } \\
\text { mencari pekerjaan }\end{array}$} & Tidak setuju & Kurang setuju & Setuju & Sangat setuju \\
\hline & & 11,11 & 14,07 & 28,15 & 46,67 \\
\hline \multirow{2}{*}{5} & \multirow{2}{*}{$\begin{array}{l}\text { Kesesuaian kemampuan } \\
\text { yang dimiliki dengan } \\
\text { kebutuhan lapangan } \\
\text { pekerjaan }\end{array}$} & Tidak sesuai & Kurang sesuai & Sesuai & Sangat Sesuai \\
\hline & & 26,67 & 42,96 & 18,52 & 11,85 \\
\hline \multirow{2}{*}{6} & \multirow{2}{*}{$\begin{array}{l}\text { Kepedulian pemerintah } \\
\text { terhadap keadaan } \\
\text { pengangguran di desa }\end{array}$} & Tidak peduli & Kurang peduli & Peduli & Sangat peduli \\
\hline & & 19,26 & 49,63 & 22,96 & 8,15 \\
\hline \multirow{2}{*}{7} & \multirow{2}{*}{$\begin{array}{l}\text { Bantuan pemerintah } \\
\text { setempat untuk menyalurkan } \\
\text { tenaga kerja }\end{array}$} & Tida ada/belum & Masih kurang & Ada & Sangat ada \\
\hline & & 58,52 & 36,30 & 4,44 & 0,74 \\
\hline \multirow{2}{*}{8} & \multirow{2}{*}{$\begin{array}{l}\text { Fasilitas pendidikan di desa } \\
\text { dapat menjadi penunjang } \\
\text { dalam mencari pekerjaan }\end{array}$} & Tidak setuju & Kurang setuju & Setuju & Sangat setuju \\
\hline & & 23,70 & 45,19 & 12,59 & 18,52 \\
\hline \multirow[t]{2}{*}{9} & \multirow{2}{*}{$\begin{array}{l}\text { Keinginan untuk mengikuti } \\
\text { pelatihan ketenagakerjaan }\end{array}$} & Tidak ingin & Kurang & Ingin & $\begin{array}{c}\text { Sangat } \\
\text { menginginkan }\end{array}$ \\
\hline & & 15,56 & 19,26 & 22,96 & 42,22 \\
\hline \multirow{2}{*}{10} & \multirow{2}{*}{$\begin{array}{l}\text { Keinginan untuk adanya } \\
\text { investor luar yang membuka } \\
\text { pabrik/usaha untuk } \\
\text { mengurangi pengangguran }\end{array}$} & Tidak ingin & Kurang & Ingin & $\begin{array}{c}\text { Sangat } \\
\text { menginginkan } \\
\end{array}$ \\
\hline & & 2,22 & 9,63 & 37,78 & 50,37 \\
\hline
\end{tabular}

Sumber: Hasil Analisis Data (2021) 
Identifikasi Permasalahan Pengangguran...

Ni Nyoman Reni Suasih \& Ni Luh Karmini

\section{SIMPULAN DAN SARAN}

Dominan penduduk di Desa Selat memilih profesi di bidang pertanian (dalam arti luas), baik sebagai petani, peternak, maupun nelayan. Selain itu, jenis pekerjaan lainnya tersebar dalam berbagai bidang, seperti industri dan jasa (formal maupun informal), wiraswasta, pemerintahan, konstruksi (buruh bangunan), dan lainnya. Pilihan pekerjaan ini terkait dengan ketersediaan lapangan pekerjaan di Desa Selat. Gambaran ketenagakerjaan di Desa Selat, dimana persentase penduduk pada usia kerja yang tidak bekerja tercatat cukup tinggi, yaitu 33,85 persen.

Meskipun permintaan tenaga kerja di Desa Selat hampir sama seperti daerah pedesaan pada umumnya, yang tidak setinggi permintaan tenaga kerja di perkotaan, namun masyarakat yang tidak bekerja enggan untuk bermigrasi ke kota. Pasar tenaga kerja tersegmentasi menjadi sektor formal dan sektor informal. Secara garis besar dapat diklasifikasikan atas faktor: (1) pendidikan, (2) keterampilan, (3) upah, (4) informasi, dan (5) ketersediaan lapangan pekerjaan. Pendidikan dan keterampilan yang dimiliki masyarakat yang belum bekerja mismatch dengan kebutuhan lapangan pekerjaan. Selain itu, adanya persepsi bahwa upah juga dianggap belum sesuai menyebabkan masyarakat memilih menganggur. Informasi dan ketersediaan lapangan kerja di lingkungan desa setempat juga masih terbatas, namun di sisi lain masyarakat sangat mengharapkan adanya investor yang dapat membuka lapangan pekerjaan di Desa Selat.
Penelitian ini bersifat eksplorasi, sehingga masih merupakan Langkah awal. Berdasarkan pembahasan sebagaimana telah dipaparkan sebelumnya, maka sebagai tindak lanjut perlu dilakukan penelitian lanjutan mengenai Mata Pencaharian Alternatif (MPA). Setelah itu mulai dilakukan tahap implementasi melalui sosialisasi ataupun penyaluran tenaga kerja. Melihat kecenderungan ini, kebijakan Pemerintah kiranya dapat diarahkan untuk investasi yang sifatnya padat karya. Pemerintah setempat dapat melaksanakan diklat maupun menyebarluaskan informasi lapangan pekerjaan bagi masyarakat yang belum bekerja. Diklat yang diberikan diharapkan dapat match dengan kebutuhan lapangan pekerjaan.

\section{REFERENSI}

Adisasmita, R. (2006). Pembangunan Pedesaan dan Perkotaan. Yogyakarta: Graha Ilmu.

Arsyad, L. (2010). Ekonomi Pembangunan. Yogyakarta: STIM YKPN.

Borjas, G. J. (2010). Labor Economic. New York: Mc Graw Hill.

Djafar, F., \& Kurniasih, E. P. (2015). Unemployment, Poverty and Indonesian Overseas Workers. Asian Journal Poverty Studies, 1(1), 30-33.

Izzaty, \& Sari, R. (2013). Kebijakan Penetapan Upah Minimum di Indonesia. Jurnal Ekonomi Dan Kebijakan Publik, 4(2), 131-145.

Jhingan, M. L. (2003). Ekonomi Pembangunan dan Perencanaan. Jakarta: PT. Raja Grafindo Persada.

Kartasasmita, G. (1996). Pembangunan untuk Rakyat. Jakarta: PT. Pustaka Cidesindo.

Knight, J., Deng, Q., \& Li, S. (2011). The puzzle of migrant labour shortage and rural labour surplus in China. China Economic Review, 22(4), 585-600. https://doi.org/10.1016/j.chieco.2011.01.006

Mankiw, N. G. (2013). Pengantar Ekonomi Makro. Jakarta: Erlangga. 
Marini, L., \& Putri, N. T. (2020). Peluang Terjadinya Pengangguran di Provinsi Bengkulu: Seberapa Besar? Convergence: The Journal of Economic Development. 1(2), 70-83. https://doi.org/10.33369/convergencejep.v1i2.10900

Riyadi, \& Bratakusumah, D. S. (2005). Perencanaan Pembangunan Daerah. Jakarta: PT. Gramedia Pustaka Utama.

Desa Selat. (2019). Profil Desa Selat. https://selat.desa.id/opensid/desa/upload/doku men/PROFIL-DESA-SELAT.doc

Siagian, S. P. (1994). Administrasi Pembangunan. Jakarta: Gedung Agung.

Sugianto, \& Permadhy, Y. T. (2020). Faktor penyebab pengangguran dan strategi penanganan permasalahan pengangguran pada desa bojongcae, cibadak lebak provinsi banten. Ikra-Ith Ekonomika, 2(3), 54-63. https://journals.upi-yai.ac.id/index.php/ IKRAITH-EKONOMIKA/article/view/583

Sukirno, S. (2006). Makro Ekonomi Modern. Jakarta: PT. Raja Grafindo Persada.

Sulistiawati, R. (2012). Pengaruh Upah Minimum Terhadap Penyerapan Tenaga Kerja dan Kesejahteraan Masyarakat di Provinsi di Indonesia. Jurnal Eksos, 8(3), 195-211.

Tikson, D. T. (2005). Teori Pembangunan di Indonesia, Malaysia dan Thailand. Makassar: Gemilang Persada.

Suryadarma, D., Suryahadi, A., Sumarto, S. (2005). The Measurement and Trends of Unemployment in Indonesia: The Issue of Discouraged Workers. Labor Economics Working Papers, SMERU Research Institute

Wijaya, P. A., Suprihanto, J., \& Riyono, B. (2020). Analisis Faktor-Faktor Penyebab Terjadinya Pengangguran dan Urbanisasi Pemuda di Desa Tamansari Kecamatan Karangmoncol Kabupaten Purbalingga Provinsi Jawa Tengah. Jurnal Pendidikan Ekonomi Undiksha, 12(1), 117-129. https://doi.org/10.23887/jjpe.v12i1.24503

Yanuar. (2009). Ekonomi Makro Suatu Analisis Untuk Konteks Indonesia (3rd ed.). Tangerang: Pustaka Mandiri. 